E Q U I L I B R I U M

2 ( 5 ) 2010

ISSN 1689-765X

\author{
Alina Manta, Roxana Nanu
}

\title{
The Impact of the Global Financial Crisis on the Management of Banking Risks
}

Key words: model, banking risk, global financial crisis, trend analysis

\begin{abstract}
The international macroeconomic and financial environment has undergone major negative changes since the global financial crisis. The magnitude and intensity of the economic and financial crisis have been underestimated by authorities worldwide. The uncertainties surrounding future developments remain high. In Romania, the main challenges posed by the external sector refer to the worsening perception of risks, including contagion effects from the adverse regional developments, the contraction of external markets, the less readily available external financing and the replacement of global liquidity risk by solvency risk. In spite of this, the banking sector continued to report positive financial soundness indicators, displaying noticeable financial results. Stress testing analyses indicate a solid absorption capacity of moderate shocks. On the other hand, we proposed ourselves to quantify the degree of correlation between the European and Romanian banking systems through the solvency indicator using the trend analysis.
\end{abstract}

\section{INTRODUCTION}

The globalized economic and financial system has changed to such an extent that central banks are on their way to becoming irrelevant. We are a long way from the supply-and-demand fundamentals of a merchandising economy, which characterized the multinationals in the 1960s and 1970s. As the credit crisis of July/ August 2007 demonstrated, rather than central bankers and regulatory authorities, it is the global financial industry that holds the upper ground.

After the crisis of the subprimes, it started to spread to other mortgages, several experts (Chorafas 2009, pp. 61) expressed the opinion that the globalization of credit risk, and most particularly of credit derivatives, holds many surprises beyond what is already known. This has proved to be one of globalization's negatives, as money centre banks and other financial entities have been making 
loans at any level of creditworthiness because that's simply raw material for securitizing and selling structured products world-wide. On the other hand, the bank activity involves risks which are manifested at the level of each bank entity, but which can be transmitted in the entire bank system or, in the case of the international banks, in more bank systems. The banks pursue the reaching of some objectives that are many times divergent, in that they use specific instruments both in order to raise its quota on the market, and also to attract available capitals necessary to the performance of some speculative transactions.

Therefore, the changing environment the banks operate in, marked by the increase of the volatility, the internationalisation and the liberalization of the financial markets increased the effect of contagion, as it was proven by the propagation of the effects of the financial crisis on the entire world bank system. Consequently, the aim of this paper is to demonstrate if there is any correlation between the European and Romanian banking systems through the solvency indicator and to analyse the changes induced by the global financial crisis on the management of the banking risks.

\section{Modern Approaches of The Global Risk}

The supervising authorities, and also the theoreticians pay nowadays a special attention to the macro prudential analysis in order to evaluate the vulnerability of the bank systems to shocks. The novelty of this recent approach, consecrated at the end of the 90's, of the last century consists in the fact that the systemic risk is analysed from the perspective of its interaction to the real economy, the focus of the supervising activity being on the contamination risk and the mutual exposure of the banks to macroeconomic shocks. We assist thus, to the minimisation of the factors specific to each bank that can have an adverse evolution and can amplify the exposure to risk.

Practically, this approach uses aggregated macro prudential quantitative indicators at the level of the bank sector (liquidity, adequate capital, the quality of the assets) and macroeconomic indicators (the GDP level and dynamics, the evolution of the inflationist process, the policy of the incomes, etc.) which concur to the establishment of the interaction between the real sector of the economy and the health of the bank system. The macro prudential analysis frame is complete when in the model are used data regarding the entire financial system and there are used techniques of the stress tests type.

We consider that the efforts of applying are considerable and the success of this type of analysis depends on the degree of integration of the financial system in every country and on the creation of some international standards so that this demarche is unitarily implemented.

The decision of the Administration Council of BNR from October 2004 through which the Direction of Financial Stability is created, having a role in the 
elaboration of some representative financial stability indicators for the supervision of the national financial system and to assure their international comparability, denotes the fact that the macro prudential analysis is agreeable by the monetary authority from our country too. The problem will be difficult, considering the structure of the Romanian financial system, and also the total liberalisation of the capital account, which will impose the Central Bank the enforcement of the supervision process for the assurance of the stability of the bank system.

Usually, the authorities use more warning in time systems, precisely to assure a high efficiency of the supervision. The Committee from Basel through the New Basel II Agreement set the basis of the consolidated supervision, considering the transnational character of the banks. Thus, the authority from the origin country must supervise, on a consolidated basis, the banks form the host countries, which does not exclude the compulsoriness of the banks from the host country in respecting the prudential norms specific to the banking market where they operate. The banks reciprocally supply themselves information regarding the management and the stock holding of these credit institutions, especially as far as the liquidity, the solvability the scheme of guarantying the deposits, the limitation of the great exposures, the accounting procedures and the internal control mechanisms are concerned.

Therefore, at the same time with the exposure of our country to the European Union, the National Bank of Romania became a member of the European System of the Central Banks, quality in which it is represented in all its work structures. This representation means the participation of the regulation process at the level of the European Union which is developed on four work levels.

Among the main benefits of this process we can find the increase of the speed of adopting the decisions by delegating the components of technical regulation to the Specialty committees and the possibility of reaching in time the convergence in the plan of the supervision practices at the competent authorities from the E.U. Among the actions taken by BNR in order to reach the convergence in the plan of the practices of supervision of the banking activities we can find:

The adapting of the reporting system of the credit institutions at the COREP requirements - Common Reporting - standardised frame of prudential reporting in the EU - and FINREP - Financial Reporting - standardised frame of financial reporting used by the prudential supervision authorities from the EU - through the configuration of their reporting forms and their integration in the reporting electronic system of NBR (National Bank of Romania 2008, pp. 45);

The use of the recommendations elaborated by the Committee of the European Bank Supervisors (CEBS);

The signing of ten bilateral memorandums with supervision institutions from the original country of the financial groups present on the Romanian market for the flexibility of the exchange of information necessary in the achievement of an efficient supervision; 
The participation to the information exchange with the supervisors from South-Eastern Europe by constructing a regional platform, as a consequence of the dominant role the subsidiaries of some foreign banks play in the financial intermediation of this region;

The promotion of a mutual supervision through the participation to twinning programs, professional training seminaries, bilateral meeting between BNR as supervision authority from the host country and those from the origin country, such as Banca d'Italia, Austrian Financial Market Authority and Austrian National Bank, Hungarian Financial Supervisory Authority and Bank of Greece.

\section{Changes induced BY THE global CRISIS TO THE MANAgement OF BANKING RISKS}

International financial turbulences which started in 2007 translated into a fullfledged crisis one year later. Starting September 2008, this crisis has intensified, affecting seriously world economic growth. The 3.2 percent international economic advance forecasted for 2008 is expected to be followed by a 1.3 percent decline in 2009 (IMF, WEO - April 2009).

In the beginning, the crisis impacted predominantly developed economies. However, the risk aversion in these countries showed rapidly through into emerging economies. The Central and Eastern Europe (CEE) region was also affected. Market sentiment began to weigh increasingly on the dynamics of spreads and of exchange rates in the CEE countries. The region was classified as a highrisk area, within which Romania is not immune and the contagion has spread from one country to another. Forecasts for the region are pessimistic: economic declines are broad-based, companies disinvest, unemployment is on the rise, current account deficits undergo adjustments and fiscal deficits widen significantly (See table 1).

Under the circumstances, restoring confidence in the favourable outlook for the region is essential. Economic activity in Romania's main trading partners (Germany, Italy and France) is expected to witness some of the largest contractions in the euro area (between -5.4 percent and -3.0 percent, EC, May 2009). Consumer confidence in these countries has seen a sharp decline, with a bearing on the demand for imports as well.

Consequently, given that Romania's export markets are adversely affected, domestic firms engaged in foreign trade activities might encounter problems. The significant depreciation of the leu starting with the autumn of 2008 has helped alleviate difficulties somehow. Exporting companies contributed by almost 16 percent to value added creation (June 2008), holding about 10 percent of loans granted (December 2008), which explains their importance to the Romanian 
economy and the banking sector. Until 2009 Q1, Romania counted among the least affected CEE countries in terms of export activity.

Table 1. Main macroeconomic indicators of countries in the area

\begin{tabular}{|c|c|c|c|c|c|c|c|c|c|c|}
\hline & \multicolumn{5}{|c|}{2008 (estimates) } & \multicolumn{5}{|c|}{2009 (forecasts) } \\
\hline & 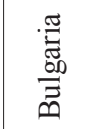 & 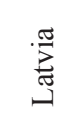 & $\begin{array}{l}\text { 己. } \\
\text { D. } \\
\Xi \\
\Xi\end{array}$ & $\begin{array}{l}\vec{\Xi} \\
\frac{\pi}{0} \\
0\end{array}$ & 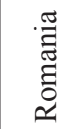 & 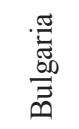 & 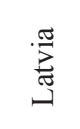 & 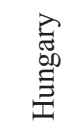 & $\begin{array}{l}\stackrel{\vec{E}}{\vec{E}} \\
\stackrel{0}{\circ} \\
0\end{array}$ & 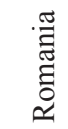 \\
\hline GDP & 6 & -4.6 & 0.5 & 4.8 & 7.1 & -1.6 & -13.1 & -6.3 & -1.4 & -4 \\
\hline $\begin{array}{l}\text { Gross fixed capital } \\
\text { formation }\end{array}$ & 20.4 & -13.2 & -2.6 & 7.9 & 19.3 & -12.7 & -24 & -10.6 & -6.2 & -6.5 \\
\hline Unemployment & 5.6 & 7.5 & 7.8 & 7.1 & 5.8 & 7.3 & 15.7 & 9.5 & 9.9 & 8 \\
\hline Inflation & 12 & 15.3 & 6 & 4.2 & 7.9 & 3.9 & 4.6 & 4.4 & 2.6 & 5.8 \\
\hline $\begin{array}{l}\text { Current account } \\
\text { deficit/GDP }\end{array}$ & -24.8 & -13.6 & -8.4 & -5.3 & -12.3 & -18.8 & -1.5 & -5 & -4.7 & -7.4 \\
\hline Public debt/GDP & 14.1 & 19.5 & 73 & 47.1 & 13.6 & 16 & 34.1 & 80.8 & 53.6 & 18.2 \\
\hline Fiscal deficit/GDP & 1.5 & -4 & -3.4 & -3.9 & -5.4 & -0.5 & -11.1 & -3.4 & -6.6 & -5.1 \\
\hline
\end{tabular}

Source: Central Bank Websites, NBR calculations, Financial Stability Report (2009).

Access to financing has become more difficult and more expensive given that (i) international creditors are reluctant to providing further liquidity, (ii) governments all over the world have started to compete strongly with the private sector for resources, and (iii) some rating agencies downgraded Romania's rating to below 'investment grade', thereby worsening the perception of sovereign risk. In 2008, Romanian companies and financial institutions resorted heavily to foreign loans, which totalled EUR 13.7 billion (thereby fuelling external debt), a volume roughly equal to the volume of new domestic bank loans granted to companies and households in 2008.

Market sentiment is weighing increasingly heavily on the setting of the financing cost for the European emerging countries. As a matter of fact, the larger resort to CDS when assessing sovereign risk (in spite of the low level of liquidity and transparency of these instruments), heightens the role played by sentiment changes while determining loan costs. The financing provided on an increasingly larger scale by the IMF to emerging countries is aimed at alleviating the pressures on the costs of and access to financing.

Financial turbulences sparked concerns over the liquidity risk management. Nevertheless, the emergence of the economic crisis enhances the probability that the solvency risk across companies might take precedence over the liquidity risk. Romania's financial stability may be affected by contagion from both directions. 
Liquidity risk: Central banks in the countries of origin of the Romanian banking capital pumped considerable amounts into their financial systems with a view to resuming lending and restoring smooth money market functioning.

Solvency risk: The economic and financial crisis is expected to generate significant losses worldwide. According to the IMF estimates (Global Financial Stability Report, April 2009), they might total almost USD 4,000 billion, of which two thirds would be incurred by banks. The decline in global economic activity and the materialisation of losses will generate contagious effects also on (I) the domestic banking sector and (II) Romania's real economy (Table 2).

Table 2. Contagion channels of the global crisis (December 2008)

\begin{tabular}{|c|c|c|c|c|c|c|}
\hline \multicolumn{3}{|c|}{ (I) via the Romanian banking sector } & \multicolumn{4}{|c|}{ (II) via Romania's economy } \\
\hline \multirow{2}{*}{ 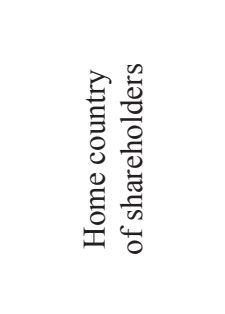 } & \multirow{2}{*}{ 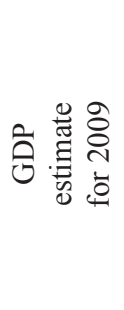 } & \multirow{2}{*}{ 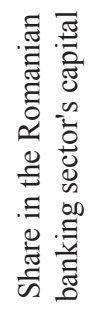 } & \multirow{2}{*}{ 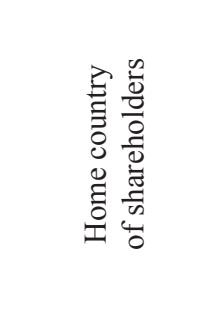 } & \multirow{2}{*}{ 官䓠 } & \multicolumn{2}{|c|}{ Share in } \\
\hline & & & & & 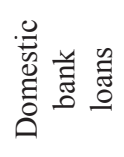 & 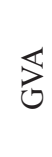 \\
\hline Greece & -0.9 & 30 & The Netherlands & -3.5 & 2.2 & 6.8 \\
\hline Austria & -4.0 & 24 & Italy & -4.4 & 1.3 & 1.5 \\
\hline The Netherlands & -3.5 & 12 & France & -3.0 & 1.2 & 3.0 \\
\hline Italy & -4.4 & 6 & Germany & -5.4 & 1.2 & 3.7 \\
\hline Hungary & $-6 ., 3$ & 6 & Austria & -4.0 & 0.9 & 3.6 \\
\hline France & -3.0 & 6 & Turkey & -3.7 & 0.6 & 0.5 \\
\hline
\end{tabular}

Source: European Commission, National Bank of Romania calculations, Financial Stability Report (2009).

Thus, the economic downturn in the countries of origin of Romanian banking capital (Table 2) will make it harder for debtors in these countries to service their debts. The solvency of parent banks will be damaged, adding to the already existing liquidity problems. Consequently, the need to recapitalise parent banks will diminish the resources they might channel towards their subsidiaries abroad. Against this background, the main foreign banks' commitment to maintaining their exposure to Romania might lessen this risk somehow.

Non-resident shareholders of companies operating in Romania may encounter difficulties in preserving their cross-border investment at the same level. As a result, foreign-owned local companies might witness a drop in the financing via this channel, which may dampen their activity. These companies hold a relatively significant share of total domestic bank loans (almost 15 percent) in value 
added formation across the economy and in Romania's external debt (more than 40 percent of both short-term debt and medium- and long-term debt, March 2009).

In 2008 and 2009 Q1, the structure of the Romanian banking sector witnessed no notable changes (Table 3). The tendency regarding territorial expansion and the rise in staff numbers was alleviated in the final part of the year amid the global financial crisis. The concentration degree which was moderate stuck to the downward path.

In 2008 and 2009 Q1, the structure of the Romanian banking sector saw no significant changes. The licensing of a foreign capital bank (BCR Banca Pentru Locuinte), the establishment of a new Bucharest-based branch (DEPFA Bank Plc. Dublin), after another bank's discontinuing activity as a result of a merger (Banca di Roma) or the changes in a bank's shareholding (ABN AMRO Bank, currently RBS Bank Romania S.A., following its being taken over by Royal Bank of Scotland) did not alter the structure of the banking sector. Starting with January 2009, CitiBank Romania S.A. changed its bank status - from Romanian legal entity with foreign capital into the Romania-based branch of Dublin-based CitiBank Europe.

At end-2008, in Romania, there were 43 credit institutions compared to 42 at end-2007, out of which 32 were licensed by the NBR to operate as Romanian legal entities, 10 branches of EU banking groups and a credit cooperative network. At end-March 2009, the number of credit institutions was unchanged, the only modification, at structure level, being the shift in status of CitiBank.

Moreover, mention should be made about the notifications regarding the intention expressed by 174 foreign institutions to provide financial services on the territory of Romania. Some of the applicants were trying to gain access to the Romanian financial market, in an attempt to receive a favourable endorsement from the supervision authorities based on the European single passport, given that cross-border operations proved to be an opportunity, especially on the corporate financing segment.

On the other hand, credit institutions in Romania, in their pursuit to gain a larger market share, further showed the tendency to expand their territorial activity by establishing 1,067 new outlets. In December 2008, 88 new outlets were registered, 6 units less than in November 2008, while in the first three months of 2009 they totalled only 65,26 and 23 respectively.

The slowdown in hiring or even the staff cuts did not have a strong impact on the number of employees in the system, which stood at 71,622 at end-December 2008 and 70,458 at end-March 2009 respectively. The two said tendencies caused the drop in the value of the indicator 'number of employees per outlet' from 12 in 2007 to 11 in December 2008 and 10.8 in March 2009.

From the viewpoint of the homeland of capital of credit institutions operating in Romania at end-March 2009, the novelty was the switch between the two 


\begin{tabular}{|c|c|c|c|c|c|c|c|c|c|}
\hline 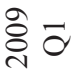 & $\stackrel{\Re}{\forall}$ & $\vec{\nabla}$ & $\hat{m}$ & $=$ & గִ & $\begin{array}{r}\hat{\sigma} \\
\hat{\sigma}\end{array}$ & $\grave{\infty}$ & $\stackrel{n}{n}$ & ஜ̊ \\
\hline$\stackrel{\infty}{\stackrel{ᄋ}{\circ}}$ & $\stackrel{m}{\forall}$ & $\bar{\gamma}$ & $\hat{n}$ & $\stackrel{ }{-}$ & ִָ & $\stackrel{\sim}{\sigma}$ & $\underset{\infty}{\infty}$ & $\begin{array}{l}\dot{\nabla} \\
\stackrel{+}{n}\end{array}$ & ปे \\
\hline 옹 & $\stackrel{\mathcal{\gamma}}{ }$ & $\stackrel{f}{+}$ & లి & $\stackrel{0}{-}$ & $\frac{9}{0}$ & デ & $\underset{\infty}{\infty}$ & $\stackrel{n}{\bullet}$ & $\begin{array}{l}0 \\
0\end{array}$ \\
\hline ஜ̊ํ․ & ले & $\hat{n}$ & $m$ & $N$ & $\frac{\infty}{0}$ & $\stackrel{n}{\not}$ & $\begin{array}{l}0 \\
\infty \\
\infty\end{array}$ & $\stackrel{n}{0}$ & $\equiv$ \\
\hline ஜ̊ & $\stackrel{\circ}{+}$ & $\underset{m}{\infty}$ & ల) & 6 & $\stackrel{0}{0}$ & $\stackrel{\circ}{\dot{J}}$ & ชู & $\begin{array}{l}\infty \\
\infty \\
\infty\end{array}$ & $\underset{\Xi}{\Xi}$ \\
\hline ષ્ઠ & $\stackrel{P}{+}$ & $\stackrel{\infty}{m}$ & 요 & $N$ & $\stackrel{\infty}{0}$ & $\ddot{a}$ & $\overrightarrow{\text { ชె }}$ & à & $\stackrel{\bigcirc}{\beth}$ \\
\hline ڤి & ले & m & จิ & $\infty$ & $\stackrel{\infty}{0}$ & ชู & $\begin{array}{l}\text { N } \\
i n\end{array}$ & ڤે & $\begin{array}{l}\text { J্ } \\
\text { I }\end{array}$ \\
\hline 공 & ले & లి & กี & $\infty$ & $\frac{\infty}{0}$ & $\begin{array}{l}0 \\
\text { in }\end{array}$ & $\underset{\bullet}{\nabla}$ & $\begin{array}{l}\infty \\
\text { ชु }\end{array}$ & $\vec{\infty}$ \\
\hline$\stackrel{\overline{8}}{\mathrm{\delta}}$ & $\bar{\nabla}$ & $\infty$ & m & $\infty$ & $\frac{\infty}{0}$ & $\begin{array}{l}\text { Na } \\
\infty \\
i n\end{array}$ & 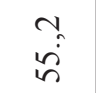 & تே: & 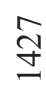 \\
\hline$\underset{\overbrace{}}{8}$ & $\bar{\nabla}$ & $\hat{n}$ & Әे & $\infty$ & $\frac{\infty}{0}$ & $\hat{a}$ & $\stackrel{\ominus}{\circ}$ & $\mathfrak{n}$ & $\stackrel{n}{n}$ \\
\hline ริ & $\vec{\nabla}$ & $\hat{n}$ & $\stackrel{\sim}{\sim}$ & $r$ & $\frac{\infty}{0}$ & $\stackrel{\sim}{n}$ & $\frac{n}{\forall}$ & Ðூ & ঐे \\
\hline & 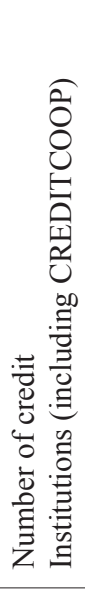 & 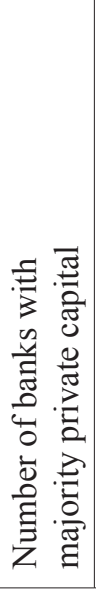 & 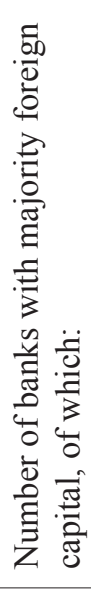 & 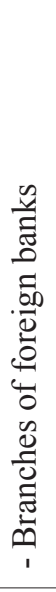 & 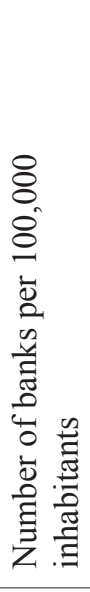 & 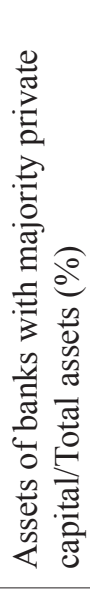 & 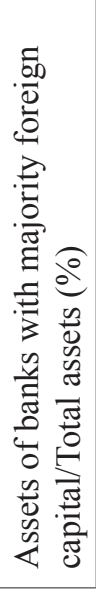 & $\begin{array}{l}0 \\
0 \\
0 \\
0 \\
0 \\
0 \\
0 \\
\frac{\pi}{0} \\
0 \\
0 \\
0 \\
0 \\
0 \\
0 \\
0 \\
0 \\
0 \\
0 \\
0 \\
0 \\
0 \\
0 \\
0 \\
0 \\
0\end{array}$ & 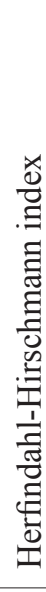 \\
\hline
\end{tabular}


top positions. Thus, in terms of capital contribution, Greece came in the lead, holding 30.7 percent of aggregate foreign capital reported at end-March 2009 by domestic banks, Austria came in second with 23.5 percent and third came the Netherlands with 11.9 percent.

The Degree of Correlation between the European Management of Banking Risks and the Romanian Management of Banking Risks through the Solvency Indicator

We proposed ourselves to identify any correlation between the development of the indicators of solvency (IS) for Great Britain, Italy, France and Romania. To this end, we introduce sets of data recorded during 1998 - 2007 using the statistical analysis program MINITAB. We first determine the trend recorded by the indicator for the period specified and based on the deviations from trend obtained we will identify the existing correlations. Values for the solvency are presented in the following table:

Table 4. The evolution of the solvency indicators

\begin{tabular}{|l|c|c|c|c|}
\hline Year & Great Britain & Italy & France & Romania \\
\hline 1998 & $13.20 \%$ & $11.30 \%$ & $10.70 \%$ & $10.25 \%$ \\
\hline 1999 & $14.00 \%$ & $10.60 \%$ & $12.70 \%$ & $17.90 \%$ \\
\hline 2000 & $13.00 \%$ & $10.10 \%$ & $11.90 \%$ & $23.80 \%$ \\
\hline 2001 & $13.20 \%$ & $10.40 \%$ & $12.10 \%$ & $28.80 \%$ \\
\hline 2002 & $12.20 \%$ & $11.20 \%$ & $12.30 \%$ & $25.00 \%$ \\
\hline 2003 & $13.00 \%$ & $11.40 \%$ & $11.90 \%$ & $21.10 \%$ \\
\hline 2004 & $12.70 \%$ & $11.60 \%$ & $11.50 \%$ & $20.60 \%$ \\
\hline 2005 & $12.80 \%$ & $10.60 \%$ & $11.40 \%$ & $21.10 \%$ \\
\hline 2006 & $12.90 \%$ & $10.70 \%$ & $10.90 \%$ & $18.10 \%$ \\
\hline 2007 & $12.60 \%$ & $10.40 \%$ & $10.10 \%$ & $13.80 \%$ \\
\hline
\end{tabular}

Source: Global Financial Stability Report, October 2008.

To estimate the trend indicator of solvency, we use the square function at the expense of the linear function because it confers a high degree of accuracy. The results obtained are presented in the following figure. 
Figure 1. Trend Analysis for Great Britain, Italy, France and Romania (results obtained from Minitab)
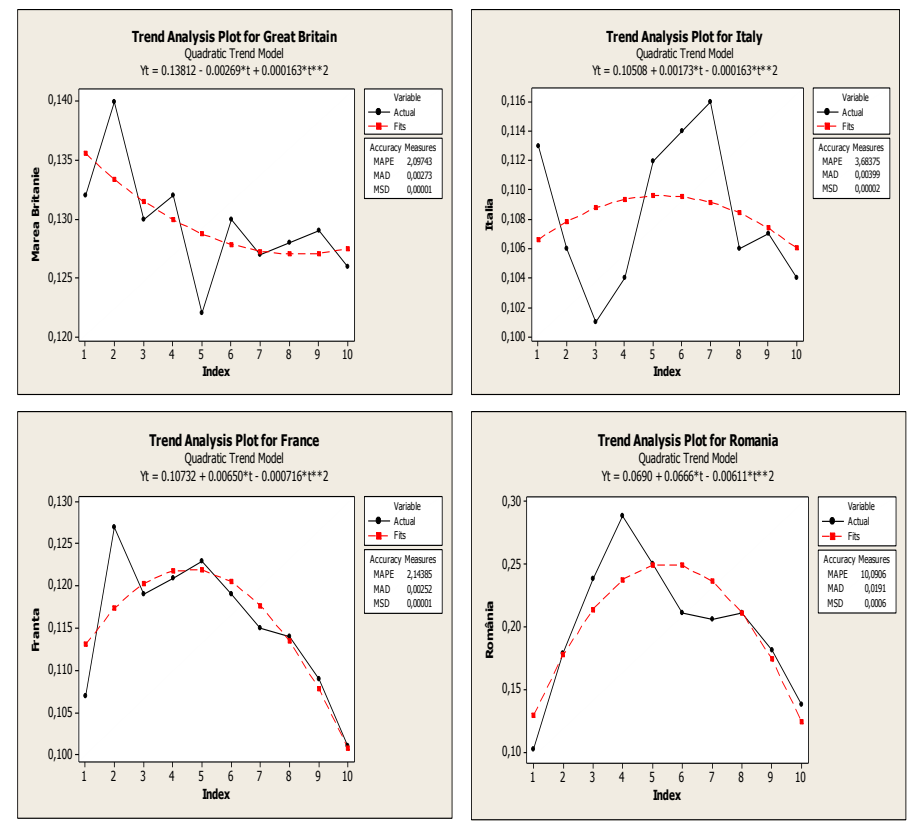

Source: own study.

Based on the results obtained, we identify correlations between deviations indicator of solvency and trend approximated by a square function in the UK, France and Italy and Romania using Pearson correlations.

Correlation coefficient varies between -1 and 1 , this meaning that:

When approaching -1 , the modification of a variable is strongly associated with the inverse linear change of the other variables;

When the correlation coefficient is equal to 0 , this means there is no association between changes of the two variables;

When the correlation coefficient approaching 1, this means that the modification of a variable is very strongly associated with linear direct modification of the other variables.

Pearson correlation reveals the following results:

Correlations: RESI_UK, RESI_RO: Pearson correlation of RESI3 and RESI10 $=0.098$, P-Value $=0.787$

Correlations: RESI_IT, RESI_RO: Pearson correlation of RESI5 and RESI10 $=-0.879$, P-Value $=0.001$

Correlations: RESI FR, RESI RO: Pearson correlation of RESI8 and RESI10 $=0.264$, P-Value $=0.461$

Therefore, one can observe a high degree of inverse correlation between risk management for solvency in the Italian banking system and the risk management 
for solvency in the Romanian banking system, and direct correlation, but low intensity between the risk of solvency of related systems French and British banks and that for the Romanian banking system. However, since the $\mathrm{p}-$ value $<0.05$ only for the correlation Italy-Romania, and for the correlations France-Romania, $p$ - value is 0,461 and for UK-Romania, $p$ - value is 0,787 , the value of $p$ is very large, it should lead us to the conclusion that there is no reason to reject the null, that there are significant differences between the risk of solvency managed by British and French banks and managed by Romanian banks. In this context, the differences are due to random events.

In conclusion, we cannot make any remarks about the correlations between the management of solvency in the French and British banking system versus the Romanian banking system because the p-value is not significant. Instead, we could observe the inverse correlation between risk management for solvency in the Italian banking system and the risk management for solvency in the Romanian banking system, which emphasizes that the two approaches for solvency risk management are very different.

\section{Conclusions}

Clearly, there is cost and benefit with global financial integration, as with any other enterprise. Worldwide access to capital is likely to bring both advantages and drawbacks. Seeking the benefits of financial integration while suffering limited costs is an impossible task - because there exist plenty of tradeoffs (and many ironies) which make the choice of a strategy complex and uncertain.

One of the ironies is that while the global market has lots of freedom, central banks lack the freedom to take necessary measures in a timely manner. Were the West's central banks to tighten monetary policy aggressively, they would bring this process of money supply expansionism under control. But aggressive tightening is not feasible at the time of a major crisis (like the subprimes) because it could bring the financial edifice down single-handed.

Knowledgeable people also say that while Western central banks lose authority, other entities are not ready to take their place. For instance, in 2006 and 2007 credit rating agencies did not act swiftly to downgrade debt. Had they done so, they would have constrained households and companies from borrowing too much, as well as having discouraged banks from buying the upper tranche of junk mortgages as Tier-1 Capital.

As for Romania, we can conclude that the banking sector continued to report positive financial soundness indicators, displaying noticeable financial results. Stress testing analyses indicate a solid absorption capacity of moderate shocks. Two vulnerabilities are more prominent, being fuelled by the global economic and financial crisis, namely credit risk and liquidity risk. Starting with the latter 
part of 2008, the quality of loan portfolio has seen a sharper deterioration, indicating particularly the slower economic activity and the weaker domestic currency. The deterioration is not even across banks, the largest ones posting higher levels of overdue and doubtful loans. In spite of the faster worsening of loan portfolios of late, the quality of these portfolios overall is in line with the EU requirements. Likewise, the coverage by provisions of non-performing loans in the balance sheets of credit institutions in Romania is higher than that reported by several EU Member States.

Capital adequacy is satisfactory both at aggregate and individual level. However, the persistent effects of the global economic and financial crisis call for the consolidation of banks with a view to withstanding potential strong shocks. To this end, the National Bank of Romania decided that banks should ensure and maintain, at least during 2009-2010, a solvency level of 10 percent at least, a prudential measure recommended by the IMF as well. Furthermore, in order to assess ex ante the need for additional capital, so as to meet the solvency threshold set forth amid a possible worsening of the economic environment, the National Bank of Romania and the IMF agreed upon carrying out some bank stress testing scenarios. The outcomes of these scenarios pinpoint the level of own funds subsequent to applying the set of shocks and, implicitly, the funds required for attaining the 10 percent solvency ratio. All banks underwent the stress testing exercise, based on stress factors included in the Government's economic programme. According to the baseline scenario used during the testing, own funds drop by about 21 percent, while in order for the solvency threshold to be attained, an additional capital contribution in amount of EUR 1 billion is still needed. Banks facing the need to bring in additional funds confirmed the intention of their shareholders to comply with the minimum 10 percent solvency requirement for 2009 and 2010.

\section{REFERENCES}

Bessis J., (2007), Risk Management in Banking, $2^{\text {nd }}$ Edition, John Wiley and Sons, LTD, pp. $460-472$.

Chorafas D., (2009), Financial Boom and Gloom - The Credit and Banking Crisis of 2007-2009 and Beyond, Palgrave Macmillan, Hampshire, pp. 61-70.

Opriţescu M. - coordinator, (2006), Management of Banking Risks and Performances, Universitaria Publishing House, Craiova, pp. 152-163.

National Bank of Romania, (2007), Annual Reports, 2004-2008.

International Monetary Fund, (2009), Global Financial Stability Report. 


\title{
WPEYW GLOBALNEGO KRYZYSU FINANSOWEGO NA ZARZĄDZENIE RYZYKIEM BANKOWYM
}

Słowa kluczowe: model, ryzyko bankowe, globalny kryzys finansowy, analiza trendu

\begin{abstract}
Abstrakt: Od czasu światowego kryzysu finansowego w środowisku międzynarodowym, makroekonomicznym i finansowym zaszły zasadnicze, negatywne zmiany. Skala i intensywność kryzysu gospodarczego zostały zaniżone przez władze na całym świecie. Niepewność co do przyszłego rozwoju wydarzeń pozostaje wciąż wysoka. W Rumunii główne wyzwania, jakie stoją przed sektorem zagranicznym, odnoszą się do pogorszenia percepcji ryzyka, w tym skutków niekorzystnego rozwoju regionalnego, kurczenia się rynków zewnętrznych, mniejszej dostępności do źródeł finansowania oraz zmiany globalnego ryzyka płynności na ryzyko niewypłacalności. Pomimo tego sektor bankowy nadal wykazywał pozytywne wskaźniki stabilności finansowej, dobrą kapitalizację oraz pokaźne wyniki finansowe. Analiza „stress testu" wykazała trwałą zdolność absorpcji umiarkowanych wstrząsów. Z drugiej strony - zaproponowano obliczenie stopnia korelacji europejskiego i rumuńskiego systemu bankowego za pomocą wskaźnika wypłacalności, używając analizy trendu.
\end{abstract}


